\title{
Nitrogen fertilization and row spacing effects on Digitaria eriantha
}

\author{
ALFREDO O. GARGANO, MIGUEL A. ADÚRIZ, AND CARLOS A. BUSSO
}

Authors are Professor and Researcher of the Consejo Nacional de Investigaciones Científicas y Técnicas de la República Argentina (CONICET) Departamento de Agronomía, Universidad Nacional del Sur (UNS), 8000 - Bahía Blanca, Argentina, Assistant Professor, Universidad Nacional del Sur (UNS), Professor and Researcher of CONICET, Departamento de Agronomia and CERZOS, Universidad Nacional del Sur (UNS).

\section{Abstract}

Crude protein (CP, \%), yield of protein dry matter (YPDM, kg $\mathrm{ha}^{-1}$ ), nitrogen use efficiency (NUE, kg dry matter $\mathrm{kg}^{-1} \mathrm{~N}$ ) and nitrogen recovery (NR, \%) were evaluated in Digitaria eriantha after exposing this species to various field-treatments during 1998-1999 and 1999-2000 in Bahía Blanca $\left(38^{\circ} 48 ' \mathrm{~S}, 62^{\circ} 13^{\prime} \mathrm{W}\right)$, Argentina. Treatments included (1) $3 \mathrm{~N}$ fertilization rates (0, 50 or $\left.100 \mathrm{~kg} \mathrm{ha}^{-1}\right)$, (2) 2 row spacings (30 or $50 \mathrm{~cm}$ ), and (3) 2 methods of fertilizer application (either split at the beginning of spring and summer or applied at once in early spring). Plants were cut leaving $5 \mathrm{~cm}$ stubble whenever they reached $26-28 \mathrm{~cm}$. Studied parameters were determined on forage harvested in spring, summer or total annual. Crude protein increased $(\mathrm{P}<0.05)$ as $\mathrm{N}$ fertilization increased in both seasons. Total annual $\mathrm{CP}$ averaged $9.7,12.0$ and $14.0 \%$, respectively for the 0,50 and $100 \mathrm{~kg} \mathrm{ha}^{-1}$ fertilization rates, respectively. Crude protein was greater $(P<0.05)$ on forage which received split rather than bulk $\mathbf{N}$ fertilization, and mean values were 13.2 and $11.7 \%$, respectively. Forage sown at different row spacings had a similar $(P>0.05)$ CP concentration. In general, YPDM responded positively $(\mathrm{P}<0.05)$ to $\mathrm{N}$ fertilization and to a split application of $\mathrm{N}$ fertilizer. Although differences were not always significant, there was an inverse relationship between $\mathbf{N}$ fertilization rate and NUE and NR. Nitrogen use efficiency was 34.5 and $24.8 \mathrm{~kg}$ dry matter $\mathrm{kg}^{-1} \mathrm{~N}(\mathrm{P}<0.05)$, and $N R$ was 98 and $79 \%(P<0.05)$ when $N$ fertilization rates were 50 and $100 \mathrm{~kg} \mathrm{ha}^{-1}$, respectively. There was a positive $(\mathrm{P}<$ $0.05)$ relationship between rainfall and NUE or NR. Nitrogen fertilization in $D$. eriantha should be split with a $\mathrm{N}$ fertilization rate close to $50 \mathrm{~kg} \mathrm{ha}^{-1}$, and using 30 rather than $50 \mathrm{~cm}$ row spacing.

Key Words: $\mathbf{N}$ rate and timing, crude protein, $\mathrm{N}$ use efficiency, $\mathrm{N}$ recovery, semiarid Argentina, perennial grasses

Research coming from semiarid environments regarding the effects of $\mathrm{N}$ fertilization on forage quality of Digitaria eriantha is scarce. Nitrogen fertilization with 100,200 or $400 \mathrm{~kg} \mathrm{ha}^{-1} \mathrm{did}$ increase crude protein (CP) in this species (Grunow and Rabie 1985). Some studies in Argentina also showed that CP increased in D. eriantha after application of 100 or $127 \mathrm{~kg} \mathrm{ha}^{-1} \mathrm{~N}$ (Veneciano and Terenti 1997, Veneciano et al. 1998). Increases in $\mathrm{N}$ or $\mathrm{CP}$ percentages as $\mathrm{N}$ fertilization rates increase in perennial grasses are common (George et al. 1972, Hanson et al. 1978, Eck et al. 1981, Madakadze et al. 1999).

Research was funded by the Universidad Nacional del Sur

Manuscript accepted 2 Feb. 2004

\section{Resumen}

Se efectuaron análisis en el forraje cosechado en un experimento realizado en Bahía Blanca (Argentina) durante los ciclos 1998-99 y 1999-00. El ensayo fue en bloques al azar con tres repeticiones. Los tratamientos fueron: 1) dosis de nitrógeno (N): 0, 50 y 100 $\mathrm{kg} / \mathrm{ha}, 2)$ distancia entre surcos: 30 y $50 \mathrm{~cm}$ y 3) sistemas de fertilización: dividida (en mitades al inicio de primavera y de vera. no) y total (al inicio de primavera). Se efectuaron cortes con frecuencia de $26-28 \mathrm{~cm}$ e intensidad de $5 \mathrm{~cm}$ de altura. En el forraje cosechado en primavera, verano y total anual se determinaron: 1) proteína bruta $(\mathrm{PB}, \%), 2)$ rendimiento de materia seca proteica (MSP, kg/ha), 3) eficiencia de utilización de $\mathbf{N}$ (EUN, kg $\mathrm{MS} / \mathrm{kg} \mathrm{N}$ ) y 4) recuperación de N (RN, \%). Todos los parámetros respondieron a la fertilización con $\mathrm{N}$. La PB aumentó con cada dosis de $N(P<0,05)$ en ambas estaciones y en el total anual. $E$ l promedio de PB total anual en las tres dosis fue: $9.7,12.0 \mathrm{y}$ $14.0 \%$, respectivamente. La $P B$ de la aplicación dividida fue mayor que la total y sus promedios fueron: 13.2 y $11.7 \%$, respec. tivamente $(P<0,05)$ y entre distancias no hubo diferencias $(P>$ 0.05). Los rendimientos de MSP respondieron, en general, a la fertilización con $\mathrm{N}$ y a su aplicación dividida $(\mathrm{P}<\mathbf{0 , 0 5})$. La EUN y la $\mathrm{RN}$ decrecieron al aumentar la dosis de $\mathbf{N}$ aunque no siem. pre significativamente. Con 50 y $100 \mathrm{~kg} / \mathrm{ha}$ de $\mathrm{N}$ la EUN total fue de 34.5 y $24.8 \mathrm{~kg} \mathrm{MS} / \mathrm{kg} \mathrm{N}(P<0,05)$, respectivamente, y la RN total fue de 98.0 y $79.0 \%$, respectivamente $(P<0,05)$. Hubo una relación positiva $(P<0,05)$ entre la cantidad de lluvia y la EUN 0 la $R N$. Se concluyó que es recomendable fertilizar con una dosis de $\mathrm{N}$ cercana a los $50 \mathrm{~kg} / \mathrm{ha}$ con aplicación dividida y sembrar en líneas a $30 \mathrm{~cm}$ en lugar de $50 \mathrm{~cm}$.

Nitrogen pollution in both surface and subsurface water is a major environmental problem and is partly due to widespread use of $\mathrm{N}$ fertilizer in agriculture. Decreasing $\mathrm{N}$ fertilization on grasslands would possibly diminish the risk of $\mathrm{N}$ leaching and runoff and would decrease the cost of production. Therefore, efforts must be focused at improving nitrogen use efficiency (NUE), that is, producing greater or similar forage dry matter yields with less $\mathrm{N}$ fertilizer. However, because nutritive value is an important consideration in perennial grasses, obtaining improved NUE should also aim at maintaining or improving forage $\mathrm{N}$ concentration to meet ruminant nutrition requirements (Minson 1982). This is important since greater dry matter yields and NUE may lead to lower N concentrations in forage grasses (Lemaire and Salette 1984).

Digitaria eriantha forms a dependable perennial base for many pasture enterprises in the southeastern Argentina. This species is also a promising alternative forage grass for livestock-forage sys- 
tems under limited nitrogen fertilizer inputs in Texas (Sanderson et al. 1999). The importance of this species has extended to southern Africa where ecotypes of Digitaria eriantha, each associated with a particular rainfall region and/or habitat conditions, have been selected suitable for restoration of denuded areas in arid and semi-arid grasslands (Theunissen 1997). Research by various rangeland ecologists (Janse Van Rensburg and Bosch 1990 , Bosch and Theunissen 1992) has revealed that Digitaria eriantha is an important pasture grass species in the semiarid grasslands of that part of the African continent. This species occupies a wide variety of soil and vegetation types and habitats over a large geographical area in southern Africa (Theunissen 1997), including grassland, savanna and woodland, and extending into marshes and along riverbanks (Chippindall and Crook 1976). Roberts (1971) and Roberts and Fourie (1975) are of the opinion that this species often occurs on sandy soils, whereas Müller (1984) states that $D$. eriantha also prefers stony soils. This species can be established using stolon scions or seeds. Although $D$. eriantha is associated with well managed vegetation, this species also becomes abundant in moderately severely overgrazed vegetation (Theunissen 1997). This involves the participation of different $D$. eriantha ecotypes. Among several perennial grasses in central Puerto Rico, D. eriantha presented the best forage acceptability by grazing animals (Ramos-Santana and McDowell 2000).

This research is a follow-up of another, previous study in $D$. eriantha (Gargano et al. 2003) where yields responded to $\mathrm{N}$ fertilization, mainly when it was split rather than applied at once. In that study, no definite yield response was observed when sowing at different row spacings. In vitro dry matter digestibility increased slightly after $\mathrm{N}$ application, and was then of doubtful biological significance. It was recommended that a $\mathrm{N}$ fertilization rate of 50-100 kg ha-1 using split applications, and $30 \mathrm{~cm}$ row spacing be used when producing $D$. eriantha. Objectives of this study were to examine the effects of row spacing and $\mathrm{N}$ fertilization on crude protein, yield of protein dry matter, nitrogen use efficiency and nitrogen recovery in $D$. eriantha. More information is needed about these parameters to manage this grass species for most efficient production in Argentina.

\section{Materials and Methods}

\section{Study Area}

This study was conducted within the semiarid region of Argentina, in Bahía Blanca (Elias and Castellvi Sentis 1996; $\left.38^{\circ} 48^{\prime} \mathrm{S}, 62^{\circ} 13^{\prime} \mathrm{W}\right)$. The most common activity in the region is cattle raising and production of light steers, which occupies $82 \%$ of the total surface area in Bahía Blanca (Gargano et al. 1990). The major forage resource for these activities is rangeland vegetation. There is some agriculture, which mostly includes wheat production. Further details on location and edaphic characteristics at the experimental site, soil tillage, sowing and plot size are given in Gargano et al. (2003). Climate data at the study area are given in Table 1 . Most relevant methodological aspects from this previous work will be briefly exposed.

\section{Experimental Design and \\ Treatments}

The experiment was a split-plot in a randomized complete block design. Studied factors and its corresponding levels were: 1) Nitrogen levels (main plots): 0,50 , or $100 \mathrm{~kg} \mathrm{ha}^{-1}$. Fertilizer was urea which was broadcasted after a rainfall or an irrigation equivalent to 3-4 mm; 2) Row spacings (main plots): 30 or $50 \mathrm{~cm}$, and 3) Fertilization methods (subplots): bulk or split fertilization. Bulk fertilization means that $\mathrm{N}$ was applied all at once in early spring, while in the split fertilization method, the total annual amount of $\mathrm{N}$ fertilizer was applied half in early spring and the other half in early summer.

Table 1. Monthly rainfall and monthly average maximum and minimum, and mean monthly air temperatures during both study cycles.

\begin{tabular}{|c|c|c|c|c|c|}
\hline \multirow[t]{2}{*}{$\begin{array}{l}\text { Annual } \\
\text { Cycle }\end{array}$} & Month & Rainfall & Maximum & $\begin{array}{l}\text { ir temperatu } \\
\text { Minimum }\end{array}$ & Mean \\
\hline & & $\cdots(m m) \cdots$ & -......... & $\left({ }^{\circ} \mathrm{C}\right)$ & (ב.....- \\
\hline \multirow[t]{8}{*}{ 1998-1999 } & September & 56.5 & 17.1 & 5.3 & 11.2 \\
\hline & October & 5.3 & 25.3 & 9.5 & 17.4 \\
\hline & November & 66.1 & 26.6 & 11.9 & 19.2 \\
\hline & December & 35.1 & 29.3 & 15.8 & 22.6 \\
\hline & January & 72.6 & 28.7 & 15.1 & 21.9 \\
\hline & February & 90.4 & 28.0 & 15.4 & 21.7 \\
\hline & March & 122.0 & 23.0 & 13.2 & 18.1 \\
\hline & April & 13.8 & 19.6 & 7.7 & 13.7 \\
\hline \multirow[t]{8}{*}{ 1999-2000 } & September & 42.0 & 18.5 & 6.7 & 12.6 \\
\hline & October & 27.0 & 22.8 & 8.9 & 15.9 \\
\hline & November & 55.0 & 25.3 & 11.9 & 18.6 \\
\hline & December & 58.0 & 28.9 & 14.7 & 21.8 \\
\hline & January & 63.0 & 32.1 & 17.6 & 24.8 \\
\hline & February & 176.0 & 27.6 & 14.8 & 21.2 \\
\hline & March & 48.0 & 24.5 & 12.9 & 18.7 \\
\hline & April & 5.0 & 22.2 & 9.2 & 15.7 \\
\hline
\end{tabular}

Each block was composed of 6 main plots ( $3 \mathrm{~N}$ levels $\mathrm{x} 2$ row spacings) and 12 subplots (6 62 fertilization methods). Numbers of treatments and replicates differ between spring and summer because of the split $\mathbf{N}$ fertilizer application. The level of $25 \mathrm{~kg} \mathrm{ha}^{-1} \mathrm{~N}$ was applied in early spring because of fractioning the $50 \mathrm{~kg} \mathrm{ha}^{-1} \mathrm{~N}$ level. As a result, the total number of treatments equaled 8 (4 $\mathrm{N}$ levels $\mathrm{x} 2$ row spacings). Number of replicates were unequal because each row spacing had 2 replicates of the 0 and $50 \mathrm{~kg} \mathrm{ha}^{-1} \mathrm{~N}$ treatments, and only 1 replicate of the 25 and $100 \mathrm{~kg} \mathrm{ha}^{-1} \mathrm{~N}$ application. However, treatment number was 12 ( $3 \mathrm{~N}$ levels $\mathrm{x} 2$ row spacings $\mathrm{x} 2$ fertilization methods) during summer and the total annual, when the experimental design was random blocks with split plots and 3 replicates.

During the growing cycle, which extends from September of 1 year to April of the following year, forage produced during spring (Sp) was harvested separately from that produced in summer $(\mathrm{Su})$. Total annual forage production was calculated as $\mathrm{Sp}+\mathrm{Su}$. At clipping, forage was hand-clipped leaving $5 \mathrm{~cm}$ stubble whenever plants reached $26-28 \mathrm{~cm}$ height. Number of clippings taken within each season and study cycle was reported by Gargano et al. (2003). Forage was dried at $65^{\circ} \mathrm{C}$ for 72 hours, weighed and ground through a cyclone mill with a $1-\mathrm{mm}$ screen for chemical analysis. Within the same dry matter subsamples obtained in that work, the following determinations were conducted: (1) Crude protein (CP, \%). Nitrogen was determined by the semimicro-Kjeldahl method (Bremner 1996) and

\section{1}


was then multiplied by 6.25 to obtain $\mathrm{CP}$; (2) Yield of protein dry matter (YPDM, kg $\left.\mathrm{ha}^{-1}\right)$. It was obtained as dry matter yield times \%CP; (3) Nitrogen-use efficiency (NUE, $\mathrm{kg} \mathrm{DM} \mathrm{kg}^{-1} \mathrm{~N}$ ). It was determined following (Novoa and Loomis 1981) as

NUE $=$ dry matter yield of fertilized plot

(kg)-dry matter yield of unfertilized plot $(\mathrm{kg})$,

Total $\mathrm{N}$ applied $(\mathrm{kg})$

and (4) Percent fertilizer $\mathrm{N}$ recovery (NR, $\%)$. It was calculated following White and Brown (1972) as

$\mathrm{NR}=\mathrm{N}$ yield in the fertilized plot

$(\mathrm{kg})$ - $\mathrm{N}$ yield in the

unfertilized plot $(\mathrm{kg}) \times 100$

Total $\mathrm{N}$ applied $(\mathrm{kg})$

\section{Statistical Analysis}

Determinations in spring were analyzed using 2-way ANOVA with unbalanced blocks but proportional replicates. A 3way ANOVA with split blocks was used to analyze summer and total annual values. Multiple comparisons were conducted using the least significant difference test. Nitrogen recovery values were transformed to arcsine $\sqrt{\%}$ for statistical analysis (Snedecor and Cochran 1971). Linear regression analysis was used to study the relationship between $\mathrm{N}$ fertilization rate and \%CP, NUE and rainfall, and NR and rainfall.

\section{Results and Discussion}

\section{Crude Protein}

There was no interaction between years and treatments for spring, summer or total annual values. Because of this, values from both study years were averaged for analysis. There was a significant $(\mathrm{P}<$ 0.05 ) relationship between $\mathrm{N}$ fertilization rate and \% $\mathrm{CP}$, and \%CP increased $(\mathrm{P}<$ 0.05 ) in forage with increased rate of $\mathrm{N}$ fertilization (Fig. 1). Increased CP percentages at higher $\mathrm{N}$ fertilization rates have been widely reported in perennial grasses (George et al. 1972, Alagarswamy et al. 1988, Cuomo and Anderson 1996, Madakadze et al. 1999). Crude protein was 0.4 to $0.9 \%$ greater at 50 than $30 \mathrm{~cm}$ row spacing but differences were not statistically significant $(P>0.05)$. Anyhow, crude protein concentrations in $D$. eriantha were high enough as to not reduce dry matter intake (Minson 1982).

During summer, only the main effects of $\mathrm{N}$ level and fertilization method were significant $(\mathrm{P}<0.05)$. Response to $\mathrm{N}$ fertilization rate in summer was similar to that in spring (Fig. 1). Crude protein concentrations were greater $(\mathrm{P}<0.05)$ when fertilization with $\mathrm{N}$ was split (13.2\%) than when it was applied all at once $(11.7 \%)$ in spring. Hanson et al. (1978) reported that applying $\mathrm{N}$ fertilizer after the first cutting in 3 perennial grass species increased second cutting forage $\mathrm{N}$ content, indicating forage responded more from a split than from a single application. Gargano et al. (2003) also reported that dry matter yields were greater in $D$. eriantha under a split than bulk application of $\mathrm{N}$ fertilizer. Bittman and Kowalenko (1998) concluded advantages, even with no yield increases, by evening out the yield and crude-protein concentration over the season.

Changes in $\mathrm{CP}$ with increasing $\mathrm{N}$ fertilization rate were equivalent to those reported for the in vitro dry matter digestibility of $D$. eriantha by Gargano et al. (2003), although the magnitude of increases was substantially different. Increases in crude protein were of 23.7 and $44.3 \%$, while those of in vitro dry matter digestibility were of 3.7 and $8.1 \%$, when $\mathrm{N}$ fertilization rates were 50 and 100 $\mathrm{kg} \mathrm{ha}^{-1}$, respectively. Increases in crude protein were greater than values reported in other studies which used $\mathrm{N}$ fertilization rates either intermediate or higher than those used in this study (Veneciano and Terenti 1997, Gargano et al. 2001). D. eriantha is expanding as a forage crop in the cattle production systems of semiarid Argentina (Frasinelli et al. 1983, Gargano et al. 1997). Use of $\mathrm{N}$ fertilization rates higher than $50 \mathrm{~kg} \mathrm{ha}^{-1}$ does not seem to be economically viable in these systems according to the obtained results.

\section{Yield of Protein Dry Matter} cantly $(P<0.05)$ so that each annual cycle was analyzed separately. Nitrogen level and row spacing interacted significantly $(\mathrm{P}$ $<0.05$ ) in spring of each study period (Table 2). Except between 25 and $50 \mathrm{~kg}$ that split applications could have practical

Years and treatments interacted signifi-
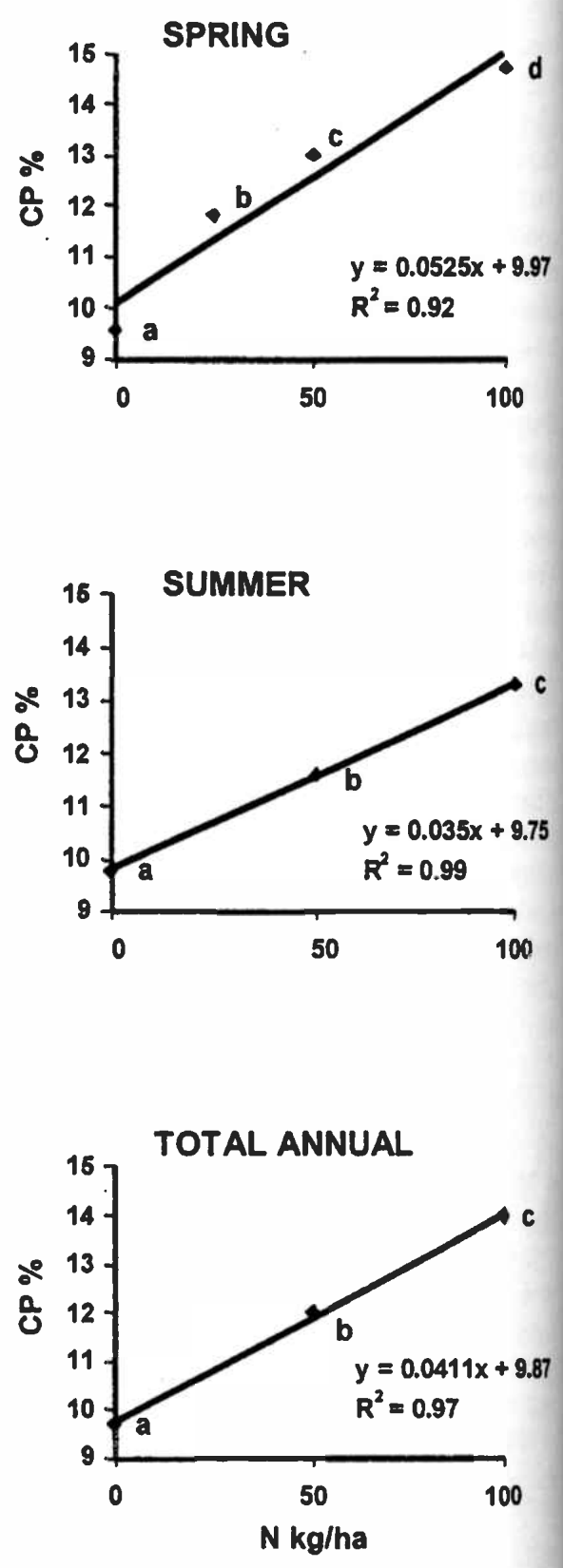

Fig. 1. Spring, summer or total annual percentage crude protein (CP) as a function of $\mathbf{N}$ fertilization rate in forage of $D$. eri. antha. Within each panel, different letters indicate significant differences at $\mathrm{P}<0.05$. Each symbol is the mean of $n=12$.

Table 2. Yields of protein dry matter $\left(\mathrm{kg} \mathrm{ha}^{-1}\right)$ during spring in each of 2 growing cycles. Values are mean \pm 1 standard error of $n=3$ for $N$ fertilization rates of 25 and $100 \mathrm{~kg} \mathrm{ha}^{-1}$ and $n=6$ for rates of $\mathrm{N}$ fertilization of 0 and $50 \mathrm{~kg} \mathrm{ha}^{-1}$.

\begin{tabular}{|c|c|c|c|c|c|}
\hline \multirow{2}{*}{$\begin{array}{l}\text { Annual } \\
\text { cycle }\end{array}$} & \multirow{2}{*}{$\begin{array}{l}\text { Row } \\
\text { spacing }\end{array}$} & \multicolumn{4}{|c|}{$\mathrm{N}$ fertilization rate $\left(\mathrm{kg} \mathrm{ha}^{-1}\right)$} \\
\hline & & 0 & 25 & 50 & 100 \\
\hline & $(\mathrm{cm})$ & $+\cdots$ & -...-- ( & ) & 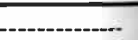 \\
\hline 1998-1999 & $\begin{array}{l}30 \\
50\end{array}$ & $\begin{array}{l}192 \pm 2.2 \mathrm{a} \dagger \\
195 \pm 2.2 \mathrm{a}\end{array}$ & $\begin{array}{l}315 \pm 7.3 \mathrm{c} \\
258 \pm 6.2 \mathrm{~b}\end{array}$ & $\begin{array}{l}339 \pm 9.7 c \\
333 \pm 3.9 c\end{array}$ & $\begin{array}{l}474 \pm 9.1 \mathrm{e} \\
425 \pm 7.2 \mathrm{~d}\end{array}$ \\
\hline 1999-2000 & $\begin{array}{l}30 \\
50\end{array}$ & $\begin{array}{l}143 \pm 6.7 b \\
116 \pm 2.4 a\end{array}$ & $\begin{array}{l}217 \pm 7.3 \mathrm{c} \\
198 \pm 2.1 \mathrm{c}\end{array}$ & $\begin{array}{l}252 \pm 2.4 \mathrm{~d} \\
274 \pm 3.0 \mathrm{e}\end{array}$ & $\begin{array}{l}299 \pm 5.6 f \\
376 \pm 7.7 g\end{array}$ \\
\hline
\end{tabular}

†Within each study period, means with a different letter are significantly different $(P<0.05)$. 
ha ${ }^{-1} \mathrm{~N}$ at $30 \mathrm{~cm}$ row spacing, yield of protein dry matter increased $(\mathrm{P}<0.05)$ as $\mathrm{N}$ fertilization rates also increased in 19981999. Yields of protein dry matter were similar or greater at 30 than at $50 \mathrm{~cm}$ row spacing. The effects of the rate of $\mathrm{N}$ fertilization and row spacing were mainly determined through its effects on dry matter yields (Gargano et al. 2003) because $\mathrm{CP}$ only responded to $\mathrm{N}$ fertilization. In 1999-2000, yield of protein dry matter depended on both dry matter yields (Gargano et al. 2003) and CP levels. As a result, all treatments responded to fertilization. The effect of row spacing did not show a consistent pattern.

During the summer of 1998-1999, only the main effects of $\mathrm{N}$ fertilization rate and method of fertilization were significant $(P$ $<0.05$ ). At this time, yield of protein dry matter increased $(\mathrm{P}<0.05)$ as $\mathrm{N}$ fertilization rate also increased (Table 3). Yields of protein dry matter were greater $(\mathrm{P}<$ 0.05 ) when fertilization was split (mean = $477 \mathrm{~kg} \mathrm{ha}^{-1}$ ) than when it was applied all at once $\left(322 \mathrm{~kg} \mathrm{ha}^{-1}\right)$.

In 1999-2000, $\mathrm{N}$ fertilization rate interacted significantly $(P<0.05)$ with row spacing within each fertilization method. Yields of protein dry matter increased $(\mathrm{P}<$ 0.05 ) as $\mathrm{N}$ fertilization rates also increased. Row spacing did not show a consistent response on yields of protein dry matter. Results confirmed once again the beneficial effects of $\mathrm{N}$ fertilization, split application of $\mathrm{N}$ fertilizer and sowing at a $30 \mathrm{~cm}$ row spacing. Yields of protein dry matter were greater $(P<0.05)$ in spring and summer of 1998-1999 than in both seasons in 1999-2000. This was the result of higher dry matter yields in the first than in the second study year (Gargano et al. 2003).

When total annual protein dry matter yields were considered, $\mathrm{N}$ fertilization rates interacted significantly $(\mathrm{P}<0.05)$ with row spacing in 1998-1999 and 19992000 within each method of fertilization (Table 4). Results reflected responses found in spring and summer, and $\mathrm{N}$ fertilization was thus the major determinant of plant responses. It increased protein dry matter yields in all treatments. Nitrogen fertilization rates of $50 \mathrm{~kg} \mathrm{ha}^{-1}$ increased yields of protein dry matter by $86 \%$ in comparison to untreated controls. Increases of protein dry matter yields with $100 \mathrm{~kg} \mathrm{ha}^{-1}$ $\mathrm{N}$ were of only $29 \%$ over values obtained when fertilizing with $50 \mathrm{~kg} \mathrm{ha}^{-1} \mathrm{~N}$. The effects of row spacing on yields of protein dry matter were inconsistent.

Table 3. Yields of protein dry matter $\left(\mathrm{kg} \mathrm{ha}^{-1}\right)$ during summer in each of 2 growing cycles. Values are mean \pm 1 standard error of $n=12$ in 1998-1999 and $n=3$ in 1999-2000.

\begin{tabular}{lccccc}
\hline \hline \multirow{2}{*}{$\begin{array}{l}\text { Annual } \\
\text { cycle }\end{array}$} & $\begin{array}{c}\text { Method of } \\
\text { fertilization }\end{array}$ & $\begin{array}{c}\text { Row } \\
\text { spacing }\end{array}$ & \multicolumn{3}{c}{$\mathrm{N}$ fertilization rate $\left(\mathrm{kg} \mathrm{ha}^{-1}\right)$} \\
\cline { 4 - 6 } $1998-1999$ & average & $(\mathrm{cm})$ & 0 & 50 & 100 \\
\hline \multirow{2}{*}{$1999-2000$} & average & $203 \pm 5.6 \mathrm{a} \dagger$ & $432 \pm 4.8 \mathrm{~b}$ & $556 \pm 6.2 \mathrm{c}$ \\
& split & 30 & $164 \pm 7.6 \mathrm{a}$ & $245 \pm 3.7 \mathrm{~b}$ & $427 \pm 8.9 \mathrm{~d}$ \\
& & 50 & $162 \pm 4.9 \mathrm{a}$ & $348 \pm 8.1 \mathrm{c}$ & $429 \pm 3.1 \mathrm{~d}$ \\
& bulk & 30 & $131 \pm 5.9 \mathrm{a}$ & $232 \pm 3.7 \mathrm{c}$ & $319 \pm 6.0 \mathrm{~d}$ \\
& & 50 & $164 \pm 2.6 \mathrm{~b}$ & $262 \pm 5.6 \mathrm{c}$ & $373 \pm 9.2 \mathrm{e}$ \\
\hline
\end{tabular}

†In 1998-1999, means with a different letter are significantly different $(\mathrm{P}<0.05)$. In 1999-2000, means with a different letter within each fertilization method are significantly different $(P<0.05)$.

Table 4. Total annual yields of protein dry matter $\left(\mathrm{kg} \mathrm{ha}^{-1}\right)$ in each of 2 growing cycles. Values are mean \pm 1 standard error of $n=3$ in 1998-1999 and 1999-2000.

\begin{tabular}{|c|c|c|c|c|c|}
\hline \multirow{2}{*}{$\begin{array}{l}\text { Annual } \\
\text { cycle }\end{array}$} & \multirow{2}{*}{$\begin{array}{l}\text { Method of } \\
\text { fertilization }\end{array}$} & \multirow{2}{*}{$\begin{array}{c}\text { Row } \\
\text { spacing }\end{array}$} & \multicolumn{3}{|c|}{$\mathrm{N}$ fertilization rate $\left(\mathrm{kg} \mathrm{ha}^{-1}\right)$} \\
\hline & & & 0 & 50 & 100 \\
\hline \multirow{3}{*}{ 1998-1999 } & & $(\mathrm{cm})$ & -------------- & $-\left(\mathrm{kg} \mathrm{ha}^{-1}\right)$ & 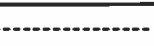 \\
\hline & split & $\begin{array}{l}30 \\
50\end{array}$ & $\begin{array}{l}368 \pm 2.6 a \dagger \\
395 \pm 4.1 b\end{array}$ & $\begin{array}{l}852 \pm 4.0 d \\
822 \pm 9.0 c\end{array}$ & $\begin{array}{l}965 \pm 9.7 \mathrm{e} \\
998 \pm 9.2 \mathrm{f}\end{array}$ \\
\hline & bulk & $\begin{array}{l}30 \\
50\end{array}$ & $\begin{array}{l}378 \pm 6.3 \mathrm{a} \\
397 \pm 9.2 \mathrm{~b}\end{array}$ & $\begin{array}{l}678 \pm 9.7 c \\
684 \pm 8.9 c\end{array}$ & $\begin{array}{r}951 \pm 3.8 \mathrm{e} \\
900 \pm 9.0 \mathrm{~d}\end{array}$ \\
\hline \multirow[t]{2}{*}{$1999-2000$} & split & $\begin{array}{l}30 \\
50\end{array}$ & $\begin{array}{l}307 \pm 5.5 \mathrm{~b} \\
288 \pm 8.1 \mathrm{a}\end{array}$ & $\begin{array}{l}462 \pm 4.2 \mathrm{c} \\
504 \pm 8.7 \mathrm{~d}\end{array}$ & $\begin{array}{l}662 \pm 9.3 \mathrm{e} \\
678 \pm 6.5 \mathrm{f}\end{array}$ \\
\hline & bulk & $\begin{array}{l}30 \\
50\end{array}$ & $\begin{array}{l}274 \pm 4.2 \mathrm{a} \\
28 \mathrm{l} \pm 8.6 \mathrm{a}\end{array}$ & $\begin{array}{l}501 \pm 2.2 b \\
522 \pm 6.2 \mathrm{c}\end{array}$ & $\begin{array}{l}618 \pm 5.6 \mathrm{~d} \\
683 \pm 9.6 \mathrm{e}\end{array}$ \\
\hline
\end{tabular}

$\lceil$ Means with a different letter within each fertilization method are significantly different $(\mathrm{P}<0.05)$.

\section{Nitrogen Use Efficiency}

Both study periods needed to be studied separately as a result of the interaction $(P$ $<0.05$ ) between study period and treatments for spring, summer and total annual data. Nitrogen fertilization rate and row spacing interacted $(P<0.05)$ in spring 1998-1999; the highest value for nitrogen use efficiency was obtained at a $\mathrm{N}$ fertilization rate of $25 \mathrm{~kg} \mathrm{ha}^{-1}$ and $30 \mathrm{~cm}$ row spacing (Table 5). In general, nitrogen use efficiency was reduced $(\mathrm{P}<0.05)$ as $\mathrm{N}$ fertilization rates increased for both row spacings although differences were not always significant. Several studies on perennial grasses have shown that NUE often decreases with increasing $\mathrm{N}$ applica- tion (Power 1985, Campell et al. 1993, Greef 1994, Liang and Mackenzie 1994, Asseng et al. 2001). It needs to be recalled, however, that efficiency of nitrogen use after fertilization may be a combination of morphological, anatomical, physiological and crop management factors (Alagarswamy et al. 1988, Gardner et al. 1994, Jiang and Hull 1998, Brégard et al. 2000). Despite being of a small magnitude, there were significant $(P<0.05)$ differences between rates of $\mathrm{N}$ fertilization and efficiency of $\mathrm{N}$ use during 1999-2000.

Nitrogen fertilization rates and row spacing interacted $(P<0.05)$ in both fertilization methods during the summer of 1998-1999 and 1999-2000 (Table 6). Of

\begin{tabular}{|c|c|c|c|c|}
\hline \multirow{2}{*}{$\begin{array}{l}\text { Annual } \\
\text { cycle }\end{array}$} & \multirow{2}{*}{$\begin{array}{c}\text { Row } \\
\text { spacing }\end{array}$} & \multicolumn{3}{|c|}{ Nitrogen fertilization rate $\left(\mathrm{kg} \mathrm{ha}^{-1}\right)$} \\
\hline & & 25 & 50 & 100 \\
\hline $1998-1999$ & $\begin{array}{c}(\mathrm{cm}) \\
30 \\
50\end{array}$ & $\begin{array}{l}28.7 \pm 3.0 \mathrm{c} \dagger \\
16.7 \pm 1.6 \mathrm{~b}\end{array}$ & $\begin{array}{l}\text { dry matter kg } \\
11.8 \pm 1.2 \mathrm{~b} \\
12.8 \pm 0.5 \mathrm{ab}\end{array}$ & $\begin{array}{c}12.0 \pm 1.2 \mathrm{ab} \\
8.0 \pm 1.0 \mathrm{a}\end{array}$ \\
\hline 1999-2000 & average & $18.2 \pm 1.2 \mathrm{c}$ & $12.9 \pm 1.3 \mathrm{~b}$ & $8.2 \pm 1.0 \mathrm{a}$ \\
\hline
\end{tabular}

†Within each study cycle, means with a different letter are significantly different $(\mathrm{P}<0.05)$. 
primary importance during 1998-1999 is the nitrogen use efficiency under $30 \mathrm{~cm}$ row spacing and $50 \mathrm{~kg} \mathrm{ha}^{-1} \mathrm{~N}$ fertilization rate in the split application method of $\mathrm{N}$ fertilizer. Nitrogen use efficiency was greater $(P<0.05)$ when the $N$ fertilizer was applied split (mean $=30.8 \mathrm{~kg}$ dry matter $\left.\mathrm{kg}^{-1} \mathrm{~N}\right)$ than all at once $(17.8 \mathrm{~kg}$ dry matter $\mathrm{kg}^{-1} \mathrm{~N}$ ) in 1998-1999. This was mainly due to the differences in dry matter yields between both fertilization methods (Gargano et al. 2003). In 1998-1999 and 1999-2000, nitrogen use efficiency was not always higher at the lowest $\mathrm{N}$ fertilization rate, and there was not a clear tendency when comparing both row spacings.

Nitrogen fertilization rate and row spacing again interacted $(P<0.05)$ when considering total annual nitrogen use efficiency (Table 7). The greatest (60 kg DM kg-1 $\mathrm{N})$ nitrogen use efficiency was found under $30 \mathrm{~cm}$ row spacing and $50 \mathrm{~kg} \mathrm{ha}^{-1} \mathrm{~N}$ fertilization rate in the split application method of $\mathrm{N}$ fertilizer. Nitrogen use efficiency was similar or greater $(\mathrm{P}<0.05)$ at 50 than at $100 \mathrm{~kg} \mathrm{ha}^{-1} \mathrm{~N}$ fertilization. There was no consistent tendency in nitrogen use efficiency when both row spacings were compared. Greater dry matter yields in 1998-1999 than in 1999-2000 (Gargano et al. 2003) determined that average total annual nitrogen use efficiency was greater $(\mathrm{P}<0.05)$ for the first $(34.2$ $\mathrm{kg}$ dry matter $\mathrm{kg}^{-1} \mathrm{~N}$ ) than for the second $\left(25.0 \mathrm{~kg}\right.$ dry matter $\left.\mathrm{kg}^{-1} \mathrm{~N}\right)$ study period. Average total annual nitrogen use efficiency was greater when fertilizing with 50 $\left(34.5 \mathrm{~kg}^{2}\right.$ dry matter $\mathrm{kg}^{-1} \mathrm{~N}$ ) than with 100 $\mathrm{kg} \mathrm{ha}^{-1} \mathrm{~N}\left(24.8 \mathrm{~kg}\right.$ dry matter $\left.\mathrm{kg}^{-1} \mathrm{~N}\right)$. Nitrogen use efficiency was satisfactory when fertilizing with $50 \mathrm{~kg} \mathrm{ha}^{-1} \mathrm{~N}$ in comparison to values obtained for this variable in other studies on D. eriantha (Veneciano and Terenti 1997, Gargano et al. 2001).

\section{Nitrogen Recovery}

Years had to be analyzed separately because of year-treatment interactions ( $P$ $<0.05$ ) for the spring, summer and total annual data. Nitrogen fertilization date and row spacing interacted significantly $(\mathrm{P}<$ 0.05 ) in spring 1998-1999 (Table 8). The greater the $\mathrm{N}$ fertilization rate, the lower the nitrogen recovery although differences were not always significant. White and Brown (1972) also showed that doubling the $\mathrm{N}$ fertilization rate decreased the percentage of $\mathrm{N}$ recovered in Stipa viridula Trin. Similar results were reported by Spratt and Gasser (1970) and Simonis (1988). Bittman and Kowalenko (1998), however, reported a greater $\%$ of $\mathrm{N}$ recovery of applied as $\mathrm{N}$ fertilization rates
Table 6. Nitrogen use efficiency (kg dry matter $\mathrm{kg}^{-1} \mathrm{~N}$ ) during summer in each growing cycle Values are mean \pm 1 standard error of $n=3$ in 1998-1999 and 1999-2000.

\begin{tabular}{|c|c|c|c|c|}
\hline \multirow{2}{*}{$\begin{array}{l}\text { Annual } \\
\text { cycle }\end{array}$} & \multirow{2}{*}{$\begin{array}{l}\text { Method of } \\
\text { fertilization }\end{array}$} & \multirow{2}{*}{$\begin{array}{c}\text { Row } \\
\text { spacing }\end{array}$} & \multicolumn{2}{|c|}{ Nitrogen fertilization rate $\left(\mathrm{kg} \mathrm{ha}^{-1}\right)$} \\
\hline & & & 50 & 100 \\
\hline \multirow{3}{*}{ 1998-1999 } & & $(\mathrm{cm})$ & -........ $(\mathrm{kg}$ & $\left.\mathrm{kg}^{-1} \mathrm{~N}\right)$ \\
\hline & split & $\begin{array}{l}30 \\
50\end{array}$ & $\begin{array}{l}45.3 \pm 2.0 \mathrm{ct} \\
30.0 \pm 1.2 \mathrm{~b}\end{array}$ & $\begin{array}{l}25.0 \pm 1.0 \mathrm{a} \\
22.7 \pm 1.1 \mathrm{a}\end{array}$ \\
\hline & bulk & $\begin{array}{l}30 \\
50\end{array}$ & $\begin{array}{l}23.0 \pm 2.0 \mathrm{c} \\
17.0 \pm 2.5 \mathrm{~b}\end{array}$ & $\begin{array}{l}20.0 \pm 1.1 \mathrm{bc} \\
11.3 \pm 1.0 \mathrm{a}\end{array}$ \\
\hline \multirow[t]{2}{*}{$1999-2000$} & split & $\begin{array}{l}30 \\
50\end{array}$ & $\begin{array}{l}10.3 \pm 4.0 \mathrm{a} \\
26.3 \pm 1.4 \mathrm{c}\end{array}$ & $\begin{array}{l}17.3 \pm 1.0 b \\
16.3 \pm 0.7 b\end{array}$ \\
\hline & bulk & $\begin{array}{l}30 \\
50\end{array}$ & $\begin{array}{l}17.0 \pm 2.4 \mathrm{~b} \\
13.7 \pm 1.0 \mathrm{ab}\end{array}$ & $\begin{array}{l}12.0 \pm 0.9 \mathrm{a} \\
13.3 \pm 1.1 \mathrm{ab}\end{array}$ \\
\hline
\end{tabular}

†Within each fertilization method, means with a different letter are significantly different $(\mathrm{P}<0.05)$.

Table 7. Total annual nitrogen use efficiency $\left(\mathrm{kg}_{\mathrm{dry}}\right.$ matter $\left.\mathrm{kg}^{-1} \mathrm{~N}\right)$ in each growing cycle. Valur are mean \pm 1 standard error of $n=3$ in 1998-1999 and 1999-2000.

\begin{tabular}{lcccc}
\hline \hline $\begin{array}{l}\text { Annual } \\
\text { cycle }\end{array}$ & $\begin{array}{c}\text { Method of } \\
\text { fertilization }\end{array}$ & $\begin{array}{c}\text { Row } \\
\text { spacing }\end{array}$ & \multicolumn{2}{c}{ Nitrogen fertilization rate $\left(\mathrm{kg} \mathrm{ha}^{-1}\right)$} \\
\cline { 3 - 5 } $1998-1999$ & \multirow{2}{*}{ split } & $(\mathrm{cm})$ & -1000 & 100 \\
& & 30 & $60.0 \pm 3.5 \mathrm{c} \dagger$ & $29.7 \pm 1.0 \mathrm{a}$ \\
& bulk & 50 & $38.3 \pm 2.0 \mathrm{~b}$ & $30.3 \pm 1.1 \mathrm{a}$ \\
& & 30 & $36.7 \pm 2.1 \mathrm{c}$ & $32.0 \pm 0.9 \mathrm{~b}$ \\
$1999-2000$ & split & 30 & $40.6 \pm 3.0 \mathrm{~b}$ & $27.8 \pm 1.7 \mathrm{a}$ \\
& & 50 & $17.0 \pm 3.2 \mathrm{a}$ & $19.0 \pm 1.0 \mathrm{a}$ \\
& \multirow{3}{*}{ bulk } & 30 & $37.3 \pm 1.2 \mathrm{c}$ & $26.3 \pm 0.9 \mathrm{~b}$ \\
& & 50 & $29.3 \pm 2.4 \mathrm{~b}$ & $16.3 \pm 1.0 \mathrm{a}$ \\
& & & $28.4 \pm 1.2 \mathrm{~b}$ & $21.8 \pm 1.1 \mathrm{~b}$ \\
\hline
\end{tabular}

$\doteqdot$ Within each fertilization method, means with a different letter are significantly different $(\mathrm{P}<0.05)$.

Table 8. Nitrogen recovery $(\%)$ during spring in each growing cycle. Values are mean \pm 1 standart error of $n=3$ for rates of $N$ fertilization of 25 and $100 \mathrm{~kg} \mathrm{ha}^{-1}$ and $n=6$ for the $N$ fertilizatio rate of $50 \mathrm{~kg} \mathrm{ha}^{-1}$ in 1998-1999, and $\mathrm{n}=6$ for the $\mathrm{N}$ fertilization rates of 25 and $100 \mathrm{~kg} \mathrm{ha}^{-1}$ and $=12$ for the $50 \mathrm{~kg} \mathrm{ha}^{-1} \mathrm{~N}$ fertilization rate in 1999-2000.

\begin{tabular}{lcccc}
\hline \hline \multirow{2}{*}{$\begin{array}{l}\text { Annual } \\
\text { cycle }\end{array}$} & Row & \multicolumn{3}{c}{ Nitrogen fertilization rate $\left(\mathrm{kg} \mathrm{ha}^{-1}\right)$} \\
\cline { 3 - 5 } & spacing & 25 & 50 & 100 \\
\hline \multirow{2}{*}{$1998-1999$} & $(\mathrm{~cm})$ & $-18.7 \pm 1.0 \mathrm{c} \dagger$ & $47.2 \pm 2.6 \mathrm{~b}$ & $43.3 \pm 1.6 \mathrm{~b}$ \\
& 30 & $49.7 \pm 4.1 \mathrm{~b}$ & $44.3 \pm 1.8 \mathrm{~b}$ & $34.3 \pm 1.2 \mathrm{a}$ \\
$1999-2000$ & average & $52.5 \pm 5.6 \mathrm{c}$ & $42.8 \pm 1.9 \mathrm{~b}$ & $32.7 \pm 1.0 \mathrm{a}$ \\
\hline
\end{tabular}

†Within each study cycle, means with a different letter are significantly different $(\mathrm{P}<0.05)$.

Table 9. Nitrogen recovery $(\%)$ during summer in each growing cycle. Values are mean \pm 1 stan dard error of $n=6$ in 1998-1999 and $n=12$ in 1999-2000.

\begin{tabular}{|c|c|c|c|c|}
\hline \multirow{2}{*}{$\begin{array}{l}\text { Annual } \\
\text { cycle }\end{array}$} & \multirow{2}{*}{$\begin{array}{l}\text { Method of } \\
\text { fertilization }\end{array}$} & \multirow{2}{*}{$\begin{array}{c}\text { Row } \\
\text { spacing }\end{array}$} & \multicolumn{2}{|c|}{ Nitrogen fertilization rate $\left(\mathrm{kg} \mathrm{ha}^{-1}\right)$} \\
\hline & & & 50 & 100 \\
\hline 1998-1999 & $\begin{array}{l}\text { split } \\
\text { bulk }\end{array}$ & $\begin{array}{c}(\mathrm{cm}) \\
\text { average }\end{array}$ & $\begin{array}{c}102.2 \pm 1.0 \mathrm{~b} \dagger \\
44.3 \pm 4.6 \mathrm{a}\end{array}$ & $\begin{array}{l}74.0 \pm 1.6 \mathrm{a} \\
41.7 \pm 1.1 \mathrm{a}\end{array}$ \\
\hline 1999-2000 & $\begin{array}{l}\text { split } \\
\text { bulk }\end{array}$ & average & $\begin{array}{r}\text { à } \\
42.5 \\
31.8\end{array}$ & \\
\hline
\end{tabular}

†Within each study cycle, means with a different letter are significantly different $(\mathrm{P}<0.05)$. 
increased. Nitrogen recovery was similar or greater $(\mathrm{P}<0.05)$ at 30 than at $50 \mathrm{~cm}$ row spacing. These results were mainly determined by dry matter yields in the different treatments (Gargano et al. 2003). In 1999-2000, nitrogen recovery decreased $(\mathrm{P}<0.05)$ as $\mathrm{N}$ fertilization rate increased. The greatest nitrogen recovery was obtained when fertilizing with $25 \mathrm{~kg} \mathrm{ha}^{-1}$ $\mathrm{N}$ in 1998-1999 and 1999-2000.

Only main effects of the 3 studied variation sources were significant $(\mathrm{P}<0.05)$ in the summer of 1998-1999. Greatest nitrogen recovery occurred when application of $50 \mathrm{~kg} \mathrm{ha}^{-1} \mathrm{~N}$ was split (Table 9). Average values for split or bulk $\mathrm{N}$ fertilization were 88.1 or $43.0 \%$, respectively. Hanson et al. (1978) also found that nitrogen recovery by Bromus inermis $\mathrm{L}$. was highest with split applications (up to 50\% recovery), but was highest for single annual applications in Phalaris arundinacea L. and Alopecurus arundinaceus L. Average nitrogen recovery was 70 or $61.5 \%$ for row spacings of 30 or $50 \mathrm{~cm}$, respectively. During the summer of 1999-2000, only the main effects method of fertilization and row spacing were significant $(\mathrm{P}<$ $0.05)$. On average, nitrogen recovery was greater $(\mathrm{P}<0.05)$ for split than bulk $\mathrm{N}$ fertilization. Also, nitrogen recovery was greater $(\mathrm{P}<0.05)$ for $50(41.7 \%)$ than 30 $(32.8 \%) \mathrm{cm}$ row spacing. The lower nitrogen recovery in the summer of 1999-2000 than in that of the previous study period was due to climatic adversities (Gargano et al. 2003). Soil nitrogen was very likely lost via ammonia volatilization (Keller and Mengell 1986, Fox et al. 1996) which intensifies if urea is used as a $\mathrm{N}$ fertilizer (Harrison and Webb 2001). Differences in N recovery values among years in herbage of $S$. viridula Trin. were related to growing conditions, especially availability of soil water (White and Brown 1972).

Nitrogen fertilization rate and row spacing interacted significantly $(P<0.05)$ in 1998-1999 and 1999-2000 when considering total annual nitrogen recovery (Table 10). Except when $\mathrm{N}$ fertilization was split at $30 \mathrm{~cm}$ row spacing in 1999-2000, nitrogen recovery was greatest at a $50 \mathrm{~kg} \mathrm{ha}^{-1} \mathrm{~N}$ fertilization rate. Nitrogen fertilization methods did not differ in nitrogen recovery because effects found in summer were masked when considering total annual results. Total annual nitrogen recovery was greater at 30 than $50 \mathrm{~cm}$ row spacing in 1998-1999, and viceversa in 1999-2000.

D. eriantha responded to $\mathrm{N}$ fertilization during its whole growing cycle. Nitrogen recovery was greatest at $50 \mathrm{~kg} \mathrm{ha}^{-1} \mathrm{~N}$ fertilization, and it was even greater than that

Table 10. Total annual nitrogen recovery $(\%)$ in each growing cycle. Values are mean \pm 1 standard error of $n=3$ in 1998-1999 and 1999-2000.

\begin{tabular}{lcccc}
\hline \hline $\begin{array}{l}\text { Annual } \\
\text { cycle }\end{array}$ & $\begin{array}{c}\text { Method of } \\
\text { fertilization }\end{array}$ & $\begin{array}{c}\text { Row } \\
\text { spacing }\end{array}$ & \multicolumn{2}{c}{ Nitrogen fertilization rate $\left(\mathrm{kg} \mathrm{ha}^{-1}\right)$} \\
\hline \multirow{2}{*}{$1998-1999$} & \multirow{2}{*}{ split } & $(\mathrm{cm})$ & -150 & 100 \\
& & 30 & $155.0 \pm 2.1 \mathrm{c} \dagger$ & $95.7 \pm 3.2 \mathrm{a}$ \\
& bulk & 50 & $118.0 \pm 4.0 \mathrm{~b}$ & $97.3 \pm 2.9 \mathrm{a}$ \\
& & 30 & $115.0 \pm 3.1 \mathrm{c}$ & $105.0 \pm 1.9 \mathrm{~b}$ \\
$1999-2000$ & split & 30 & $53.6 \pm 2.8 \mathrm{~b}$ & $78.7 \pm 1.0 \mathrm{a}$ \\
& & 50 & $87.7 \pm 3.3 \mathrm{c}$ & $68.7 \pm 2.0 \mathrm{a}$ \\
& \multirow{2}{*}{ bulk } & 30 & $72.3 \pm 2.7 \mathrm{~b}$ & $55.0 \pm 2.0 \mathrm{~b}$ \\
& & 50 & $81.7 \pm 1.9 \mathrm{c}$ & $73.7 \pm 1.8 \mathrm{~b}$ \\
\hline
\end{tabular}

†Within each fertilization method, means with a different letter are significantly different $(\mathrm{P}<0.05)$.

Table 11. Correlation coefficients (r) and predictive equations with significance levels (p) for Nitrogen Use Efficiency (NUE, $\left.\mathrm{kg} \mathrm{DM} \mathrm{kg} \mathrm{N}^{-1}\right)$ as a function of rainfall $(R, \mathrm{~mm})(\mathrm{NUE}=\mathrm{a}+\mathrm{bR})$ during both annual cycles. Values of NUE during spring were related to rainfall from 1 September to 17 December in 1998, and from 1 September to 22 December in 1999. During summer, NUE values were related to rainfall from 17 December 1998 to 15 April 1999, and from 22 December 1999 to 3 April 2000. Finally, values of total annual NUE were related to rainfall from 1 September to 15 April in 1999, and from 1 September to 3 April in 2000 . Within each annual cycle, values used in the regression analysis correspond to both row spacings and methods of nitrogen fertilization.

\begin{tabular}{lccccc}
\hline \hline Annual cycle & Fertilization rate & $\mathrm{a}$ & $\mathrm{b}$ & $\mathrm{R}$ & $\mathrm{P}=$ \\
\hline \multirow{3}{*}{$1998-1999$} & $--\left(\mathrm{kg} \mathrm{ha}^{-1}\right)---$ & & & & \\
& 50 & -3.12 & 0.105 & 0.76 & 0.006 \\
$1999-2000$ & 100 & -0.25 & 0.067 & 0.89 & 0.000 \\
& 50 & 0.86 & 0.057 & 0.63 & 0.041 \\
& 100 & 2.50 & 0.0395 & 0.79 & 0.007 \\
\hline
\end{tabular}

obtained at the same experimental site after fertilizing $D$. eriantha winterdeferred forage with $60 \mathrm{~kg} \mathrm{ha}^{-1} \mathrm{~N}$ in midsummer (Gargano et al. 2001). Additionally, when $\mathrm{N}$ fertilization rate of $50 \mathrm{~kg} \mathrm{ha}^{-1}$ was split, nitrogen recovery was similar or greater than highest values obtained for this parameter in studies where split application of 100 to $127 \mathrm{~kg}$ $\mathrm{ha}^{-1} \mathrm{~N}$ was made in the semiarid region (Veneciano and Terenti 1997, Veneciano et al. 1998). This demonstrates that $\mathrm{N}$ fer-

Table 12. Correlation coefficients ( $r$ ) and predictive equations with significance levels (p) for Nitrogen Recovery $(\mathrm{NR}, \%)$ as a function of rainfall $(\mathrm{R}, \mathrm{mm})(\mathrm{NR}=\mathrm{a}+\mathrm{bR})$ during both annual cycles. Values of NR during spring were related to rainfall from 1 September to 17 December in 1998, and from 1 September to 22 December in 1999. During summer, NR values were related to rainfall from 17 December 1998 to 15 April 1999, and from 22 December 1999 to 3 April 2000. Finally, values of total annual NR were related to rainfall from 1 September to 15 April in 1999, and from 1 September to 3 April in 2000 . Within each annual cycle, values used in the regression analysis correspond to both row spacings and methods of nitrogen fertilization.

\begin{tabular}{lccccc}
\hline \hline Annual cycle & Fertilization rate & $\mathrm{a}$ & $\mathrm{b}$ & $\mathrm{R}$ & $\mathrm{P}=$ \\
\hline \multirow{3}{*}{$1998-1999$} & $--\left(\mathrm{kg} \mathrm{ha}^{-1}\right)---$ & & & & \\
& 50 & 0.80 & 0.267 & 0.82 & 0.007 \\
$1999-2000$ & 100 & 6.30 & 0.192 & 0.89 & 0.002 \\
& 50 & 16.60 & 0.120 & 0.70 & 0.073 \\
& 100 & 13.00 & 0.107 & 0.86 & 0.018 \\
\hline
\end{tabular}


and clay soils. Water supply is the most important factor in achieving high NUE, with the highest NUE in wheat having been reported under irrigation (Fisher et al. 1993). Whitfield and Smith (1992) reported a higher NUE under irrigation than under rainfed conditions. Garabet et al (1998) also found that NUE is increased by higher rainfall and irrigation.

\section{Conclusions}

All studied parameters in $D$. eriantha responded significantly to $\mathrm{N}$ fertilization, which corroborates results found in a previous work (Gargano et al. 2003). In this study, however, it was made clearer the convenience of applying a $\mathrm{N}$ fertilization rate close to $50 \mathrm{~kg} \mathrm{ha}^{-1} \mathrm{~N}$. Even though values of some parameters significantly increased when fertilizing with 100 rather than $50 \mathrm{~kg} \mathrm{ha}^{-1} \mathrm{~N}$, they were in general of a small magnitude and then of doubtful biological and/or economical significance. Additionally, NUE and NR were greater when fertilizing with 50 than with $100 \mathrm{~kg}$ $\mathrm{ha}^{-1} \mathrm{~N}$. Because of this, and given that cultivation of $D$. eriantha is fostered in semiarid regions for cattle raising, which is per se a cattle production system of low productive efficiency, it would not be recommended to fertilize with more than $50 \mathrm{~kg}$ $\mathrm{ha}^{-1} \mathrm{~N}$.

Split $\mathrm{N}$ fertilization and row spacing of $30 \mathrm{~cm}$ are recommended over bulk $\mathrm{N}$ fertilization or $50 \mathrm{~cm}$ row spacing. However, row spacing did not have a major relevance on the results. It is likely that a 50 $\mathrm{cm}$ row spacing could improve plant responses under conditions of water stress greater than those registered during the second study period.

\section{Literature Cited}

Alagarswamy, G., J.C. Gardner, J.W. Maranville, and R.B. Clark. 1988. Measurement of instantaneous nitrogen use efficiency among pearl millet genotypes. Crop Sci. 28 681-685.

Asseng, S., N.C. Turner, and B.A. Keating. 2001. Analysis of water- and nitrogen-use efficiency of wheat in a Mediterranean climate. Plant and Soil 233:127-143.

Bittman, S. and C.G. Kowalenko. 1998. Whole-season grass response to and recovery of nitrogen applied at various rates and distributions in a high rainfall environment. Canadian J. Plant Sci. 78: 445-451.

Bosch, O.J.H. and J.D. Theunissen. 1992. Differences in the response of species on the degradation gradient in the semi-arid grass- lands of southern Africa and the role of ecotypic variation. p. 95-109. In: G.P. Chapman (ed) Desertified grasslands: Their biology and management. London, U.K.: Academic Press.

Brégard, A., G. Bélanger, and R. Michaud. 2000. Nitrogen use efficiency and morphological characteristics of timothy populations selected for low and high forage nitrogen concentrations. Crop Sci. 40:422-429.

Bremner, J.M. 1996. Nitrogen-Total. p. 1085-1123. In: D.L. Sparks, A.L. Page, P.A. Helmke, R.H. Loeppert, P.N. Soltanpour, M.A. Tabatabai, C.T. Johnston and M.E. Sumner (eds) Methods of Soil Analysis. Part 3. Chemical Methods. Wisconsin, USA: Amer. Soc. of Agron.

Campbell, C.A., R.P. Zentner, F. Selles, B.G. McConkey, and F.G Dyck. 1993. Nitrogen management for spring wheat grown annually on zero-tillage: Yields and nitrogen use efficiency. Agron. J. 85:107-114.

Chippindall, L.K.A. and A.O. Crook. 1976. Grasses of Southern Africa. M.O. Collins, Salisbury.

Cuomo, G.J. and B.E. Anderson. 1996. Nitrogen fertilization and burning effects on rumen protein degradation and nutritive value of native grasses. Agron. J. 88:439-442.

Eck, H.V., G.C. Wilson, and T. Martinez. 1981. Tall fescue and smooth bromegrass. II. Effects of nitrogen fertilization and irrigation regimes on quality. Agron. J. 73:453-456.

Elias, F. and F. Castellvi Sentis. 1996. Clasificaciones climáticas, In: Agrometeorología, pp. 279-315. Ediciones MundiPrensa, Madrid, España.

Fisher, R.A., G.N. Howe and Z.M. Ibrahim. 1993. Irrigated spring wheat and timing and amount of nitrogen fertilizer. 1. Grain yield and protein content. Field Crops Res. 33:37-56.

Fox, R.H., W.P Piekielek, and K.E. Macneal. 1996. Estimating ammonia volatilization losses from urea fertilizers using a simplified micrometeological samples. Soil Sci. Soc. Amer. J. 60:596-601.

Frasinelli, C.A., A. Marchi, and C.G. Giraudo. 1983. Efecto de la fertilización nitrogenada sobre la calidad del pasto llorón (Eragrostis curvula (Schard) Nees) cv. Tanganyika diferido. Producción Animal 10:297-307.

Garabet, S., J. Ryan, and M. Wood. 1998. Nitrogen and water effects on wheat yield in a Mediterranean-type climate. II. Fertilizeruse efficiency with labelled nitrogen. Field Crops Res. 58:213-221.

Gardner, J.C., J.W. Maranville, and E.T. Paparozzi. 1994. Nitrogen use efficiency among diverse sorghum cultivars. Crop Sci. 34:728-733.

Gargano, A.O., M.A. Adúriz, and M.C. Saldungaray. 1990. Sistemas agropecuarios de Bahía Blanca. 1. Clasificación y descripción mediante índices. Revista Argentina de Producción Animal 10:361-371.
Gargano, A.O., M.A. Adúriz, and M.C Saldungaray. 1997. Evaluación de Digitari eriantha y Eragrostis curvula durante el ciclo de crecimiento y en diferimiento. 1 . Rendimientos de materia seca. Revist Argentina de Producción Animal 17:365-373.

Gargano, A.O., M.A. Adúriz, and M.C. Saldungaray, 2001. Yield and quality fertilized deferred forage of Eragrostis curvula and Digitaria eriantha. J. Arid Environ. 47 181-189.

Gargano, A.O, M.A. Adúriz, C.A. Busso and M.I. Amela. 2003. Nitrogen and ror spacing on Digitaria eriantha production and digestibility. J. Range Manage. 56:483-488.

George, J.R., C.L. Rhykerd, G.O. Mott, R.F. Barnes, and C.H. Noller. 1972. Effect $d$ nitrogen fertilization of Festuca arundinaces Schreb. on nitrate nitrogen and protein con: tent and the performance of grazing steers Agron. J. 64:24-26.

Greef, J.M. 1994. Productivity of maize (Zee mays L.) in relation to morphological and physiological characteristics under varying amounts of nitrogen supply. Crop Sci. 172 317-326.

Grunow, J.O. and J.W. Rabie. 1985. Production and quality. J. Grassl. Soc. Sout Africa 2, 23-28.

Hanson, C.L., J.P. Power, and C.J. Erikson 1978. Forage yield and fertilizer recovery $b$ three irrigated perennial grasses as affecte by $\mathrm{N}$ fertilization. Agron. J. 70:373-375.

Harrison, R. and J. Webb. 2001. Effect of । fertilizer type on gaseous emissions. Ad Agron. 73:67-108.

Janse Van Rensburg, F.P. and O.J.H. Bosct 1990. Influence of habitat differences on tx ecological grouping of grass species on grazing gradient. J. Grassl. Soc. of Southen Africa $7: 11-15$.

Jiang, Z. and R.J. Hull. 1998. Interrelation ships of nitrate uptake, nitrate reductase, an nitrogen use efficiency in selected Kentuck bluegrass cultivars. Crop Sci. 38:1623-1632

Keller, G.D. and D.B. Mengell. 1986 Ammonia volatilization from nitrogen ferti izers surface applied to no-till corn. Soil Sci Soc. Amer. J. 50:1060-1063.

Lemaire, G. and J. Salette. 1984. Relatiot entre dynamique de croissance et dynamiqux de pre-lèvement d'azote pour un peuplemen de gramine-es fourragères. II. Étude de variabilite- entre genotypes. Agronomie 4 431-436.

Liang, B.C. and A.F. Mackenzie. 1994. Con yield, nitrogen uptake and nitrogen use effi ciency as influenced by nitrogen fertilization Can. J. Soil Sci. 74:235-240.

Madakadze, I.C., K.A. Stewart, P.R Peterson, B.E. Coulman, and D.L. Smith 1999. Cutting frequency and nitrogen ferti ization effects on yield and nitrogen concer tration of switchgrass in a short season are Crop Sci. 39:552-557.

Minson, D.J. 1982. Effects of chemical an physical composition of herbage eaten upo 
intake. p. 167-182 In: (J.B. Hacker, Ed) Nutritional limits to animal production from pastures. Slough, UK: Commonwealth Agr. Bureaux.

Müller, M.A.N. 1984. Grasses of South West Africa/Namibia. Directorate of Agriculture and Forestry, Windhoek.

Novoa, R. and R.S. Loomis. 1981. Nitrogen and plant production. Plant and Soil 58:117-204.

Power, J.F. 1985. Nitrogen- and water-use efficiency of several cool-season grasses receiving ammonium nitrate for 9 years. Agron. J. 77:189-192.

Ramos-Santana, R. and L.R. McDowell. 2000. Agronomic comparison of six bermudagrasses from southern United States with five tropical grasses in central Puerto Rico. J. Plant Nutrition 23:711-717.

Roberts, B.R. 1971. Habitat preferences of twenty-seven grasses. Proc. Grassl. Soc. of Southern Africa 6:44-49.

Roberts, B.R. and J.H. Fourie. 1975. Common grasses of the Northern Cape. Northern Cape Livestock Cooperative, Vryburg.
Sanderson, M.A., P. Voigt, and R.M. Jones. 1999. Yield and quality of warm-season grasses in central Texas. J. Range Manage. 52:145-150.

Simonis, A.D. 1988. Studies on nitrogen use efficiency in cereals. In: Nitrogen efficiency in Agricultural Soils, Elsevier Applied Science Publishers, London, England. p. 110-124

Snedecor, G.W. and W.G. Cochran. (Eds) 1971. Métodos estadísticos. México: Compañía Editorial Continental.

Spratt, E.D. and J.K.R. Gasser. 1970. Effects of fertilizer nitrogen and water supply on distribution of dry matter and nitrogen between the different parts of wheat. Can. J. Plant Sci. 50:613-625.

Theunissen, J.D. 1997. Selection of suitable ecotypes within Digitaria eriantha for reclamation and restoration of disturbed areas in southern Africa. J. Arid Environ. 35:429-439.
Veneciano, J.H. and O.A. Terenti. 1997. Efectos de la defoliación y la fertilización nitrogenada en el rendimiento y calidad de Digitaria eriantha Steudel subsp. eriantha cv. Irene. Revista de la Facultad de Agronomía UNLPam. 9:41-56.

Veneciano, J.H., O.A. Terenti, and E.R. Del Castello. 1998. Variación estacional de rendimientos y calidad de Digitaria eriantha con y sin fertilización. Inf. Técn. 146. E.E.A. INTA San Luis, 29 pp.

White, L.M. and J.H. Brown. 1972. Nitrogen fertilization and clipping effects on green needlegrass (Stipa viridula Trin.): II. Evapotranspiration, water-use efficiency, and nitrogen recovery. Agron. J. 64:487-490.

Whitfield, D.M. and C.J. Smith. 1992. Nitrogen uptake, water use, grain yield and protein content in wheat. Field Crops Res. 29:1-14. 